\title{
O projeto "As Cores da Vida" na celebração do Ano Brasileiro do Ensino Religioso
}

\author{
"As Cores da Vida" Project at Brazilian \\ Religious Education Year
}

\section{Claudino Gilz}

Professor das Faculdades Associadas de Ensino (FAE), universitário coordenador geral de Ensino Religioso na Associação Franciscana de Ensino Senhor Bom Jesus, Curitiba, PR - Brasil, e-mail: claudinogilz@hotmail.com

\section{Resumo}

O presente artigo tem como objetivo analisar as principais implicações à disciplina de Ensino Religioso, provenientes dos fenômenos socioculturais que compõem o atual contexto, de modo especial a necessidade de superação dos preconceitos religiosos, das marginalizações, das diferenças, das polarizações e dos fundamentalismos. Discute a contribuição que o Ensino Religioso pode oportunizar por meio de proposta pedagógica e curricular composta de um conjunto temático, gradativamente distribuído em trimestres letivos, pertinentes ao estudo das manifestações do fenômeno religioso, com objetivos estabelecidos e com enfoque adequados à faixa etária do corpo discente. Apresenta 
os detalhes do processo de elaboração e de implementação do Projeto "As Cores da Vida", em comemoração ao Ano Brasileiro do Ensino Religioso, proclamado em 15 de novembro de 2009, na Associação Franciscana de Ensino Senhor Bom Jesus.

Palavras-chave: Ensino Religioso. Plano curricular. Ano Brasileiro do Ensino Religioso.

\section{Abstract}

The present article aims to analyze the main implications of Religious Education subject, coming from the social and cultural phenomena that forms the current context, in particular the need of overcoming religious prejudices, depravedness, diversities, polarization and fundamentalisms. It discusses about the contribution Religious Education may offer through academic and education plan compounded of a thematic group, gradually distributed in quarters relevant to the study of manifestations of religious phenomenon, with established objectives and approaches according to the age of the students. It also presents the process' implementation details of the project "As Cores da Vida", in celebration of Brazilian Religious Education Year acclaimed on November 15th, 2009, at Associação Franciscana de Ensino Senhor Bom Jesus.

Keywords: Religious Education. Academic plan. Brazilian Religious Education Year.

\section{Introdução}

O espaço escolar tem se transformado num canteiro no qual as esperanças de uma nova humanidade sinalizam estar germinado. O Ensino Religioso é, na atualidade, uma disciplina escolar voltada à intencionalidade de promover o respeito à pluralidade cultural religiosa em sala de aula. Intencionalidade essa que se circunscreve num contexto histórico-cultural em constante mudança e, por esse motivo, repleto de iniludíveis interpelações. Interpelações?

Interpelações oriundas dos fenômenos da globalização, do urbanismo, da instauração de novas relações familiares, da aspiração por 
maior prevalência dos parâmetros éticos e da consideração à pluralidade cultural, étnica e religiosa. Interpelações cuja veemência evoca um processo de aprendizagem escolar capaz de sensibilizar os diversos para o diálogo, o mútuo respeito e o compromisso por construir uma sociedade mais justa e solidária.

O Ensino Religioso tem, nesse sentido, procurado responder às referidas interpelações ao tornar viável ao corpo discente o conhecimento dos diversos caminhos de identificação da manifestação do Transcendente. $\mathrm{O}$ Ensino Religioso procura responder às referidas interpelações ao compreender o ser humano como um ponto de convergência de aspirações e relações. O Projeto “As Cores da Vida” é uma dessas iniciativas de resposta não só à celebração do Ano Brasileiro do Ensino Religioso, mas também a todas as questões que se acercam da existência humana.

\section{Compondo o mosaico do atual momento histórico em que se celebra o Ano Brasileiro do Ensino Religioso}

O atual momento histórico no qual se celebra o Ano Brasileiro do Ensino Religioso apresenta-se permeado de complexidades. Tanto os progressos da ciência como os espaços abertos pela comunicação ainda não fizeram dirimir a necessidade de superação dos preconceitos religiosos, das marginalizações, dos reducionismos, das diferenças, dos isolamentos, dos ceticismos, dos dualismos, das polarizações e dos fundamentalismos. E por que não fizeram?

Constata-se não ser suficiente identificar preconceitos religiosos, marginalizações, reducionismos, diferenças, isolamentos, ceticismos, dualismos, polarizações ou fundamentalismos (BOFF, 2002). Constata-se também não ser reparador perceber algumas mudanças em processo ou outras já consolidadas. O mosaico do atual momento histórico no qual se celebra o Ano Brasileiro do Ensino Religioso compõe-se de vários aspectos a serem considerados e estudados com seriedade.

Oprimeirodeles dizrespeitoaoriscodeportar-sedesapercebidamente como simples e passivo espectador de uma história que acontece, com ou sem o empenho de comprometer-se a protagonizar um processo de permanente discernimento de como não viver à mercê dos condicionamentos, os mais diversos. $\mathrm{O}$ constante movimento migratório de pessoas do campo 
para a cidade, da cidade à metrópole e até de um país a outro é um desses condicionamentos a instaurar novos desafios, a questionar os sistemas educacionais vigentes, tanto nos seus conteúdos como nos seus métodos formativos. Pois quem chega não se apresenta isento de um cabedal mínimo de princípios, costumes, parâmetros éticos e religiosos (ALVES; ALVES, 2009). Ou seria possível continuar formando as demandas escolares à margem desse fenômeno?

A potencialização da insegurança, do medo, da criminalidade, da violência, da injustiça, da guerra, do apreço ao imediato e ao conformismo são alguns dos outros aspectos a formar o atual momento histórico. Geram tensões e afetam as tradições e os legados herdados das gerações anteriores. Embasam procedimentos pedagógicos nos quais o aluno não passa de um simples receptor de conhecimentos transmitidos pelo professor e um mero objeto da ação formativa (GRUEN, 1995). Tornam-se obstáculo à descoberta das implicações oriundas dos conhecimentos científicos, humanísticos, artísticos, religiosos e culturais. Inibem a eficiência de um processo de aprendizagem capaz de remeter para a arte de ler a realidade com espírito crítico e cívico. Por que não abrir caminho para uma revalorização da rica diversidade das tradições religiosas e das possibilidades de uma vida digna para todos, especialmente para os mais pobres? Por que não pesquisar os meios de instaurar mediações para o diálogo entre os diversos e os aparentemente incompatíveis?

O Ensino Religioso, quando desenvolvido em um ambiente de liberdade e respeito aos diversos, contribui para o discernimento de respostas consistentes ante as interrogantes existenciais do ser humano. Ser humano esse que se vê, num momento, às voltas com objetivos, pensamentos, sentimentos, desejos, sonhos, decisões, valores e convicções, e noutro, ávido por conhecer mais e mais o seu mundo interior e se aceitar com serenidade - pois se define como um fenômeno inédito no modo de ser, de pensar, de sentir, de optar e, por isso mesmo, detentor de uma unidade composta de múltiplas dimensões, articuladas entre si.

Jalal ud-Din Rumi (1996, p. 43), considerado um dos maiores poetas e místicos de toda a tradição persa e árabe, afirma: "seja teu amor deste ou do outro mundo, terminará por conduzir-te à outra margem”. O ser humano encerra em si uma expressão religiosa. O seu modo de ser, vestir-se, alimentar-se, interpelar-se diante do mistério ou suster a sua sobrevivência não deixa de ser, em si, uma experiência religiosa. 
Mesmo que a religião se apresente profundamente enraizada nos indivíduos, ela veio a ser sistematizada e estruturada em meio a um grupo social, a uma cultura. Mitos, ritos, símbolos, dogmas, artigos de fé, moral, ascese, meditação, oração, pacto, aliança e mística estão entre os elementos mais comuns a uma religião ou tradição religiosa. Todavia, a etimologia do conceito "religião" remete para o ato humano de religar, de unir e de trazer sempre de novo à escuta e ao pulsar do próprio coração a inspiração divina que o circunscreve. Religião é mais do que uma opção pessoal ou uma confessionalidade. Religião é um caminho de realização e plenitude humana. Religião é uma inspiração que permite encontrar respostas às mais diversas perguntas. Religião é, enfim, o que sempre tem ajudado o ser humano a deixar transparecer o melhor de si em termos de amorosidade, compaixão, reverência e encantamento.

O ser humano, quando vive sob o enfoque da sua dimensão religiosa, aprende a viver da gratuidade e da singeleza. Irradia a alegria de transcender-se a cada passo, a cada sonho realizado, a cada esperança aninhada na sacralidade da vida e do coração. De acordo com Bonhoeffer (1991,p. 15), "o ser humano, em sua origem, só sabe de uma coisa: Deus. A outra pessoa, as coisas, a si mesmo ele só conhece na unidade de seu saber de Deus".

Qualquer visão fragmentária do ser humano queda-se ante a descoberta de sua realidade última, ou seja, unitária e integral. Privilegiar várias dimensões em detrimento da religiosa é fadar o ser humano à inglória errância destituída de sentido. Embora o ser humano seja constituído de uma dimensão religiosa, a transcendência é o seu maior desafio existencial. Pois ela se define como a irrupção do divino a partir de dentro (da interioridade) do ser humano (HARADA, 2006).

O nascimento, no ser humano, do sonho de transcendência é no mínimo um mistério a ser melhor compreendido. Um mistério que leva o ser humano a entrever-se na busca de respostas em relação a inúmeras questões, tais como: quem criou e dirige o universo? Por que ser bom? Qual o sentido da vida, do sofrimento? Por que existe o mal no mundo? O que se pode esperar para além da morte? "Nasceste dos filhos dos filhos de Deus, mas fixaste muito abaixo a tua mira. Como podes ser feliz assim? Vem! Retorna à raiz da raiz de ti mesmo" (RUMI, 1996, p. 104). Em outras palavras, do empenho pela busca de transcender-se a cada passo é dado ao ser humano alcançar as alegrias da Plenitude Divina. Da indiferença, a razão pela qual despende seus dias na mais irresoluta infelicidade. 
O Ensino Religioso evoca a articulação das perspectivas científica, simbólica e religiosa da vida no conjunto de suas manifestações (GIL FILHO, 2009). Uma evocação que leva a perceber a vida não apenas do ponto de vista natural, mas também como dádiva da sabedoria e do amor do Transcendente.

Pode-se dizer que qualquer processo educacional tornar-se-ia inviável se ignorasse as aspirações e relações que compõem o viver humano. A relação incondicional com o Transcendente é uma delas. "Uma crença pode continuar a reger a ação, [...] mesmo entre pessoas que estão plenamente conscientes de que essa crença não é causada por nada de mais profundo do que as circunstâncias históricas contingenciais” (RORTY, 1992, p. 239).

Inaugura-se, assim, no Ensino Religioso, um processo educacional a serviço da humanização do espírito cívico do corpo discente, mesmo em meio às incertezas que irrompem da configuração do trocadilho: vive-se não só uma época de mudanças, mas também uma mudança de época. Uma mudança de época circunscrita por novos modelos de pessoa, de família e de sociedade e, em consequência, também de inovações nos sistemas educacionais e na formação de professores.

A configuração de um mundo cada vez mais globalizado [...] tem caminhado para uma utopia de homegeneização. É nesse mundo complexo e antagônico que a escola tem sido convidada a repensar suas configurações [...] e os cursos de formação de professores (MARIANO, 2007, p. 109-116).

O Ensino Religioso é uma disciplina escolar guardiã de uma proposta educacional cujo objeto de estudo são as manifestações do fenômeno religioso e, por isso mesmo, voltada a educar para o respeito às diferenças. $\mathrm{O}$ respeito, por excelência, às diferenças religiosas. Impele a comunidade escolar a fazer uma hermenêutica crítica dos acontecimentos e a recolher o significado da vida sob a perspectiva do mistério divino que a envolve. Contrapondo-se a isso, identificam-se inúmeras atitudes humanas no embate cotidiano, veiculadas pela mídia e, consequentemente, invejadas pela grande massa expectadora. Tais atitudes são, na verdade, apenas o ícone eloquente de quem para tudo serve, menos para ser apresentado como referencial de caráter, de beleza, de dignidade, de cidadania ou de vivência dos princípios religiosos. Enquanto a mídia aposta no aumento 
do Ibope a qualquer custo, o Ensino Religioso aposta numa proposta pedagógica voltada à redescoberta da sacralidade da vida, enunciada pelas diversas tradições religiosas.

Assiste-se diariamente a um conjunto de loucuras em defesa da vida. As tradições religiosas afirmam que a vida é um dom sagrado que se recebe do Transcendente e, a partir dessa concepção, desdobra-se toda uma leitura religiosa da vida, dos fatos, acontecimentos. Quando entregue a uma iniciação religiosa, o ser humano autoproclama-se um agente de bons sentimentos e capaz de partilhá-los durante a sua breve passagem por esse mundo. Faz a experiência de transcender-se diante do Mistério da Vida e da ressonância de seus sentimentos mais íntimos. Ocupa ele um lugar nesse mundo limitado e, ao mesmo tempo, infindo. Abre-se à possibilidade de identificar sinais do Transcendente no outro e no diferente de si. Entrega-se cotidianamente à oração para agradecer, para pedir e se abrir à inspiração do além. Chega a compreender-se a cada instante como parte integrante das realidades transcendentes que evoca e nas quais acredita. Faz-se portador da transcendência ao esmerar-se para que ela irrompa nele a partir de dentro, e encerre essencialmente em si uma religiosidade. Mostra-se reverente ao Transcendente que se manifesta como caminho, resposta e sentido mais profundo do seu viver. Por que viveria o ser humano tão somente na esfera do profano e do efêmero, se pode trazer sempre de novo à escuta e ao pulsar do próprio coração a fala do Transcendente que o plenifica?

Ao longo da história da humanidade, o termo religião veio a ser entendido como cultos, práticas, doutrinas e aspectos morais inerentes à formação religiosa em que as pessoas são criadas. Religião define-se antes de tudo como uma atitude fundamental do ser humano, cujos desdobramentos podem ser observados por meio dos tempos nas mais diversas culturas. Fato é: o ser humano, quando vive sob o enfoque da sua dimensão religiosa, aprende a viver da gratuidade, da eloquência do silêncio e da serenidade na dor, aprende a demonstrar apreço pela singeleza, pela convivialidade, pela doação de si e pela emoção de transcender-se a cada esperança aninhada na sacralidade da vida e do coração.

O que se poderia esperar do docente e do aluno que cursa a disciplina de Ensino Religioso, senão sensibilidade humana e religiosa, abertura para o diálogo, capacidade de escuta interior e apreço incondicional ao diálogo? No entanto, achegar-se da compreensão do universo religioso só pode se dar de forma gradativa, respeitando-se o ritmo de cada um dos envolvidos. 
Por essas e tantas outras razões, o ano de 2010 não é, do ponto de vista da disciplina de Ensino Religioso, um momento histórico estanque. A proclamação do Ano Brasileiro do Ensino Religioso (de 15 de outubro de 2009 a 15 de outubro de 2010) não pode ser entendida como uma decisão sem precedentes ou unilateral. Ela traz consigo tanto a ressonância de uma história já de mais de cinco séculos de aprendizagem dos temas relacionados ao fenômeno religioso, nas suas mais diversas manifestações, como a aspiração de fazer memória aos esforços empreendidos na construção da identidade pedagógica do Ensino Religioso como disciplina escolar e área de conhecimento. Por que fazer menção a isso?

Porque a proclamação do Ano Brasileiro do Ensino Religioso se fez com uma evocação lançada a todos os professores de Ensino Religioso das escolas e colégios do Brasil: organizar eventos científicos, encontros, palestras, reuniões de estudos, debates e seminários, no intuito de fazer memória da história, do legado pedagógico e cívico da referida disciplina no atual contexto escolar.

$\mathrm{Na}$ Associação Franciscana de Ensino Senhor Bom Jesus (AFESBJ), essa evocação foi acolhida de bom grado e comprometimento desde o primeiro momento. A seguir, alguns detalhes dos encaminhamentos realizados e do Projeto "As Cores da Vida", implementado pela coordenação geral e por cada um dos professores de Ensino Religioso da AFESBJ, desde meados do mês de outubro de 2009.

\section{Ensino Religioso na AFESBJ e a celebração do Ano Brasileiro do Ensino Religioso por meio do projeto "As Cores da Vida"}

O atual cenário da disciplina de Ensino Religioso na AFESBJ decorre do ato de sancionamento da Lei n. 9.475 de 22 de julho de 1997 (BRASIL, 1997), que legitimou nova redação ao artigo 33 da Lei n. 9.394 de 20 de dezembro de 1996 (BRASIL, 1996) e serviu de referência para a elaboração de um Plano Curricular e de uma coleção composta de dez livros didáticos de Ensino Religioso como recursos didáticos, seja do estágio final da educação infantil, seja dos anos do ensino fundamental. De que maneira?

Durante quase cinco séculos da história do Brasil, o nome mais utilizado para a atual disciplina do Ensino Religioso tinha sido "Aula de Religião" (FIGUEIREDO, 1996). Um tempo histórico que abrangeu 
períodos como o Brasil Colônia, o Brasil Império e o Brasil República. História cuja atualidade registra uma mudança na forma e no conteúdo: da Aula de Religião ao Ensino Religioso.

O Ensino Religioso, implementado em sala de aula na AFESBJ desde o ano de 1997, dispõe de uma estruturação escolar própria: proposta pedagógica, plano curricular, metodogia, livro didático, professores afins e qualificados. A disciplina de Ensino Religioso é oportunizada à comunidade escolar com objeto de estudo definido: o fenômeno das manifestações religiosas, sem deixar de desinstalar os alunos a se abrirem à necessidade de discernimento do que buscam ser, seja como pessoas constituídas de uma dimensão religiosa, seja como cidadãos brasileiros. É o Ensino Religioso na AFESBJ uma disciplina, enfim, embasada no ideário de acolher o aluno e educá-lo, tanto para o cultivo de sua dimensão religiosa, quanto para o diálogo, o respeito ao diferente de si e a construção da paz. Porque, para além de uma prescrição em Lei (BRASIL, 1997) - a prescrever o respeito à diversidade cultural religiosa do Brasil, vedadas quaisquer formas de proselitismo em sala de aula -, vale lembrar que hoje não somente o espaço escolar mas a sociedade brasileira e mundial se constituem a partir da diversidade.

O plano curricular de Ensino Religioso é, na AFESBJ, composto especificamente por temas de estudo com propósitos pedagógicos claros e com enfoque adequados à faixa etária. Temas de estudo cuidadosa e gradativamente distribuídos em trimestres letivos, abrangendo, como já foi mencionado, o estágio final da educação infantil, os anos do ensino fundamental e os do ensino fundamental. Os temas de estudo contemplados no Plano Curricular de Ensino Religioso da AFESBJ das referidas etapas têm até então procurado assegurar na íntegra o desenvolvimento de tais premissas. Foram pensados e definidos, buscando abranger a totalidade da vida humana nos seus mais insondáveis mistérios e nas situações mais casuais do cotidiano humano. Foram pensados e definidos, buscando considerar os Planos Curriculares Nacionais de Ensino Religioso, os fundamentos legislativos e pedagógicos da disciplina.

Por meio de depoimentos feitos em congressos científicos dessa área de conhecimento, constata-se o contrário. Por não haver um plano curricular com um conjunto temático definido para o Ensino Religioso, o que normalmente se tem feito nas aulas da disciplina em muitas escolas públicas e particulares do Brasil? Desenvolvimento tão somente de atividades avulsas e fragmentadas a respeito de valores. 
$\mathrm{Na}$ AFESBJ, a elaboração do plano curricular de Ensino Religioso oportunizou e postulou a observância de critérios tanto no ato da escolha de qualquer material ou recurso didático para o desenvolvimento das aulas, como na definição da qualificação profissional dos professores contratados para ministrar a disciplina.

Não havendo nenhum livro didático no mercado editorial capaz de atender às prerrogativas do plano curricular de Ensino Religioso implementado na AFESBJ, a partir do sancionamento da já citada Lei n. 9.475 (BRASIL, 1997), os próprios professores que na época ministravam a disciplina se decidiram em empreender uma ousadia: elaborar eles próprios livros didáticos para a etapa da educação infantil e os anos do ensino fundamental. Foi por essa ousadia que, após quase três anos, em meados de 2001, era publicada pela Editora Vozes a Coleção "Redescobrindo o Universo Religioso".

Na primeira edição, a referida coleção era composta de 11 livros didáticos. Ao passar por um processo de atualização textual e também de ilustrações, a Coleção "Redescobrindo o Universo Religioso" foi redimensionada para dez volumes didáticos. Assim como o Plano Curricular deEnsino Religioso da AFESBJ, a coleção tem a intencionalidade pedagógica de fomentar no corpo discente, a partir da diversidade das confessionalidades, a redescoberta dos caminhos de uma convivência fraterna entre os diversos, isentos de tendências doutrinárias de uma determinada religião. Uma intencionalidade também voltada ao propósito de levar o aluno a reconsiderar a sua destinação humana sob o ponto de vista da dimensão religiosa de que se constitui, a saber mais da suposta iniciação religiosa que tenha recebido no contexto familiar ou da comunidade confessional de que participa, a conhecer o fenômeno religioso no conjunto de suas manifestações e tradições.

Um dos diferenciais didáticos da Coleção "Redescobrindo o Universo Religioso" consiste em estabelecer uma sintonia entre conhecimento, crença e experiência da transcendência de si e o processo gradativo de redescobrir a dimensão religiosa a partir do contexto pessoal, familiar, cultural, social e religioso do aluno. Consiste em discorrer sobre os temas de forma dinâmica, visando a despertar e educar a religiosidade inerente a cada pessoa (aluno). Consiste, enfim, em se apresentar como um dos elementos formativos do profissional que a utiliza em sala de aula, pois, segundo pesquisa já realizada (GILZ, 2009), mostrou-se um substrato para reconstrução da experiência 
religiosa; detentora de uma intencionalidade educativa peculiar voltada à alteridade; articuladora de uma metodologia propositiva, sensível à faixa etária dos alunos e estimuladora da criatividade docente.

Não é demasiado voltar a afirmar que a diversidade cultural e religiosa é um fato dentro e fora da sala de aula. As tratativas de celebração do Ano Brasileiro do Ensino Religioso na AFESBJ pretendiam, desde o momento de sua proclamação, contemplar tal constatação na sua íntegra. O que passou a ser providenciado?

Na semana seguinte ao dia 15 de outubro de 2009, a coordenação geral de Ensino Religioso da AFESBJ reuniu-se e definiu alguns encaminhamentos, a saber:

- construção de uma proposta pedagógica de forma colegiada e participativa com os professores de Ensino Religioso das unidades escolares da AFESBJ;

- sondagem via e-mail com os já mencionados professores de possíveis ideias de como se poderiam organizar encaminhamentos pedagógicos que fizessem jus à celebração do Ano Brasileiro do Ensino Religioso, sem que fossem paralelos ao Plano Curricular da disciplina, vigente na educação infantil e nos anos do ensino fundamental.

A referida sondagem consistia da seguinte questão aos professores da disciplina: se você fosse organizar uma amostra celebrativa do Ano Brasileiro do Ensino Religioso, como faria? Ao receber as sugestões enviadas pelos professores de Ensino Religioso das unidades da AFESBJ, a coordenação geral voltou a reunir-se e a estudar as mais diversas propostas.

Após três reuniões empreendidas, chegou-se à elaboração de uma proposta comum, o que se denominou de projeto "As Cores da Vida" com as seguintes partes:

- introdução, motivações e orientações gerais de como implementar o projeto "As Cores da Vida", por meio do protagonismo dos professores de Ensino Religioso de cada uma das unidades da AFESBJ;

- explicação do processo de elaboração do logotipo do projeto, que culminou na caracterização de um conjunto diverso de cores, ou 
seja, um círculo de cores variadas, cada uma com sua coloração própria. A escolha do nome ao projeto "As Cores da Vida" decorreu do intuito de vincular o conceito das cores à diversidade da vida e das manifestações religiosas presentes no mundo;

- proposição dos temas de estudo de acordo com o Plano Curricular referente à etapa da educação infantil: A vida e as atitudes são como presentes; - proposição dos temas de estudo de acordo com o Plano Curricular referente à etapa do ensino fundamental: $1^{\circ}$ ano-Maneiras de falar com o Transcendente; $2^{\circ}$ ano - Regra de Ouro das Religiões; $3^{\circ}$ ano - Os diversos nomes do Transcendente; $4^{\circ}$ ano - Templos Religiosos; $4^{\mathrm{a}}$ série Tradição Orale Escrita; $5^{\text {a }}$ série-Origem das Religiões, Símbolos Religiosos, Principais Festas; $6^{\mathrm{a}}$ série - Lideres Religiosos; $7^{\mathrm{a}}$ série - Coexistência (cuidado com o meio ambiente, com o outro e o Transcendente); $8^{a}$ série - O papel do jovem nas comunidades religiosas;

- sugestão dada aos professores da disciplina na semana pedagógica de fevereiro para que elaborassem, a partir do projeto "As Cores da Vida", um planejamento de possíveis atividades a serem desenvolvidas em sala de aula no decorrer do $1^{\circ}$ e início do $2^{\circ}$ semestre de 2010. As atividades poderiam, fazendo uso o quanto possível de material alternativo (reciclável), abranger: pesquisa sobre a memória de como eram as aulas de Ensino Religioso vivenciadas pelos familiares (pais, avós, etc.) dos alunos; entrevista com pessoas das diferentes denominações religiosas; registro de visita a lugares sagrados da região em que o colégio se encontra situado; concurso de frases individuais ou coletivas que retratem o respeito pela diversidade cultural e religiosa; servir-se de fotografias, trajes típicos, vestimentas, curtas metragem, maquetes, alimentos sagrados, livros sagrados, símbolos religiosos, músicas pertinentes a cada tradição religiosa (islâmica, budista, hindu, etc.), textos coletivos, gincana, teatro, dioramas representando os lugares sagrados, histórias em quadrinhos, modelagem, cartazes, fotos, reportagens, paródias, curiosidades sobre as religiões, dança, móbiles, feira de livros sobre as diversas religiões, jogral, linha do tempo (mapa das religiões no mundo), recortes de gravuras de revistas ou jornais, poemas, acrósticos;

- sugestão de data para exposição dos registros das atividades realizadas em sala de aula, da educação infantil e do ensino 
fundamental, para a semana de 23 a 28 de agosto, com possibilidade de ser feita em outro momento mais oportuno da unidade, durante o segundo semestre letivo.

No decorrer do primeiro semestre letivo, a Coordenação Geral de Ensino Religioso da AFESBJ realizou diversos contatos com os responsáveis pela gestão e pela assessoria pedagógica das unidades, buscando prestar esclarecimentos e também obter informações sobre como estava o andamento dos trabalhos. A referida coordenação serviu-se também do apoio da equipe de profissionais de comunicação e marketing da AFESBJ, tanto para a confecção de materiais (roteiro de orientação de como compor a exposição dos registros das atividades realizadas em sala de aula, cartaz, flyers, banners, camisetas, etc.), com o objetivo de servir de apoio e reforço da promoção do referido projeto, bem como para desenvolver um espaço na web com a intenção de divulgar as atividades antes e durante a mostra.

Até o presente momento, a Coordenação Geral de Ensino Religioso da AFESBJ tomou conhecimento das seguintes iniciativas empreendidas pelos professores das unidades:

a) Propostas de atividades do Nível C e D (educação infantil): entre as várias atividades desenvolvidas em sala de aula sobre o tema "A vida e as atitudes são como presentes", sugeridas pela Coleção "Descobrindo o Universo Religioso: Educação Infantil” (livro do aluno e livro do professor) e pelo Plano de Atividades recebido da Coordenação Geral de Ensino Religioso, vale mencionar:

- roda de conversa com os alunos sobre a importância da vida de todos os seres vivos; construção de um painel, representando a importância da vida dos diferentes seres vivos;

- utilização de caixinhas vazias e higienizadas como embalagens de presentes a serem decoradas pelas crianças com as cores diferentes possíveis, para, com isso, trabalhar a diversidade cultural e religiosa; - solicitação do envolvimento da família, por meio dos alunos, à elaboração de uma caixa de presente com a intenção de, dentro dela, colocar uma foto da família, com desenhos de atitudes que possam ser consideradas presentes pelas crianças;

- e construção de um texto coletivo sobre o tema. 
b) Propostas de atividades do $1^{\circ}$ ano (ensino fundamental): entre as várias atividades desenvolvidas em sala de aula sobre o tema "Diferentes formas de falar com Deus", sugeridas pelo volume 1 da Coleção de Livros Didáticos, "Descobrindo o Universo Religioso" (livro do aluno e livro do professor) e pelo Plano de Atividades recebido da Coordenação Geral de Ensino Religioso, vale mencionar:

- painel de desenhos a respeito dos diferentes momentos de oração em família;

- criação da história de um menino que gostaria de aprender a rezar/orar e que passou a observar como as pessoas rezavam, ou seja, seus avós, pais, amigos, vizinhos e tantas outras pessoas, chegando a perceber, ao fim, várias maneiras pelas quais se pode falar com Deus;

- registro da referida história em uma espécie de livrão a ser feito e ilustrado pelos próprios alunos;

- elaboração de uma oração continuada da turma;

- pesquisa, pelos alunos, de informações sobre os modos como as comunidades religiosas próximas ao lugar onde eles vivem se comunicam com o Transcendente, com exposição das informações obtidas em um painel na unidade escolar.

c) Propostas de atividades do $2^{\circ}$ ano (ensino fundamental): entre as várias atividades desenvolvidas em sala de aula sobre o tema "A regra de ouro das religiões", sugeridas pelo volume 2 da Coleção de Livros Didáticos, "Descobrindo o Universo Religioso" (livro do aluno e livro do professor) e pelo Plano de Atividades recebido da Coordenação Geral de Ensino Religioso, vale mencionar:

- construção de um livreto por parte de cada aluno, com figuras ou desenhos, representando atitudes que não aprovaria ou que aprovaria que os outros fizessem a ele, com o objetivo de tornar acessível aos estudantes a interpretação da "regra de ouro das religiões";

- confecção de cartões postais a serem enviados a pessoas da família, da escola e ao secretário da Educação do município em que a unidade escolar se encontra situada, contendo menções às atitudes ensinadas pela "regra de ouro" das religiões; - elaboração e apresentação de histórias com fantoches; 
- pesquisa em meios de informação (livros, revistas, internet, entre outros) sobre as mais variadas versões da "regra de ouro", dando atenção especial àquelas que estejam ligadas a comunidades religiosas e, com a ajuda do professor, compreender o significado das referidas versões encontradas durante a pesquisa;

- confecção em sala de aula, por meio de materiais recicláveis, de cartazes com as versões da "regra de ouro" encontradas na referida pesquisa, com cores distintas;

- entrevistas com a direção, a assessoria pedagógica, os professores e funcionários da unidade escolar, buscando sugestões de como se poderia chegar a uma regra de ouro a inspirar a convivência de todos ali, diariamente, exposta em faixa no pátio interno;

- proposição de se contruir uma história em quadrinhos para demonstrar como a "regra de ouro" pode ser colocada em prática no ambiente escolar, familiar e social.

d) Propostas de atividades do $3^{\circ}$ ano (ensino fundamental): entre as várias atividades desenvolvidas em sala de aula sobre o tema "Os diversos nomes do Transcendente”, sugeridas pelo volume 3 da Coleção de Livros Didáticos, "Descobrindo o Universo Religioso" (livro do aluno e livro do professor) e pelo Plano de Atividades recebido da Coordenação Geral de Ensino Religioso, vale mencionar:

- pesquisa em sites que tenham informações sobre o significado dos nomes dos alunos. Após pesquisa, cada aluno registraria com escrita e com desenho o significado do seu nome. Em seguida, a pesquisa continuaria, mas a respeito do significado do nome do Transcendente em algumas religiões (Judaísmo, Cristianismo, Islamismo, Hinduísmo, Tribais africanos, Testemunhas de Jeová e outras tradições religiosas), com o objetivo de perceber as diferentes maneiras de como o Transcendente é invocado. Como atividade final, exposição, por meio de móbiles no teto da sala de aula, dos nomes atribuídos ao Transcendente encontrados; - proposição de uma história em quadrinhos, resgatando os nomes atribuídos ao Transcendente pelo menos de duas religiões;

- elaboração de uma listagem com o maior número de nomes atribuídos ao Transcendente descobertos pelos colegas de turma por meio de uma pesquisa; 
- composição de uma paródia com um ou mais dos nomes atribuídos ao Transcendente, podendo ser gravada em vídeo e apresentada aos pais.

e) Propostas de atividades do $4^{\circ}$ ano (ensino fundamental): entre as várias atividades desenvolvidas em sala de aula sobre o tema "Templos Religiosos", sugeridas pelo volume 4 da Coleção de Livros Didáticos, "Descobrindo o Universo Religioso" (livro do aluno e livro do professor) e pelo Plano de Atividades recebido da Coordenação Geral de Ensino Religioso, vale mencionar:

- estudo e coleta de informações sobre as características principais, específicas e curiosas dos templos das comunidades religiosas, por meio de gravuras, ilustrações, fotos ou vídeos;

- confecção de maquetes, com caixa de sapato ou outros materiais recicláveis, de diferentes templos religiosos;

- estudo, buscando identificar quais são os principais templos das comunidades religiosas estudadas (havendo a possibilidade de se buscar por aquelas que não o são). Nessa busca, os alunos deverão colher o maior número de informações sobre o templo escolhido, sendo que gravuras, fotos, vídeos, entre outras, serão muito bemvindas. A finalidade da pesquisa será a posterior construção de maquetes de templos religiosos em sala de aula. É conveniente que as maquetes sejam construídas por grupos de no máximo três alunos e, indispensavelmente, com material reciclável.

f) Propostas de atividades da $4^{a}$ série (ensino fundamental): entre as várias atividades desenvolvidas em sala de aula sobre o tema "Tradição Oral e Escrita”, sugeridas pelo volume 5 da Coleção de Livros Didáticos, "Descobrindo o Universo Religioso" (livro do aluno e livro do professor) e pelo Plano de Atividades recebido da Coordenação Geral de Ensino Religioso, vale mencionar:

- realização de pesquisa com os pais dos alunos sobre relatos de tradição oral de família e registro em pequenos livros dos dados colhidos, principalmente dos princípios religiosos familiares partilhados de geração em geração, podendo ilustrá-los;

- confecção em pergaminhos de frases de textos sagrados de diferentes tradições religiosas; 
- desenvolvimento de estudos a respeito de como na região em que se encontra a unidade escolar foram, até então, se estabelecendo as tradições religiosas de cunho oral e escrita, com a incumbência dos alunos comporem uma linha do tempo delas, seja com dados históricos explicativos, seja com ilustrações, fotos ou documentários disponibilizados pelas próprias tradições.

g) Propostas de atividades da $5^{\mathrm{a}}$ série (ensino fundamental): entre as várias atividades desenvolvidas em sala de aula sobre o tema "Origem das Religiões, Símbolos Religiosos, Principais Festas”, sugeridas pelo volume 6 da Coleção de Livros Didáticos, "Descobrindo o Universo Religioso" (livro do aluno e livro do professor) e pelo Plano de Atividades recebido da Coordenação Geral de Ensino Religioso, vale mencionar:

- tiragem de fotos de símbolos religiosos existentes na família de cada aluno com o intuito de montagem de um livreto, contendo as informações obtidas;

- desenvolvimento de estudos a respeito da origem das tradições religiosas que se encontram estabelecidas na região circunvizinha à unidade escolar;

- levantamento das festas religiosas desses mesmas tradições religiosas de janeiro a dezembro;

- realização de um concurso de frases sobre símbolos religiosos;

- confecção de móbiles dos símbolos religiosos das tradições religiosas que se encontram estabelecidas na região circunvizinha à unidade escolar;

- montagem de um folder explicativo sobre a origem das religiões, símbolos religiosos, locais de culto e principais festas das tradições religiosas que se encontram estabelecidas na região circunvizinha à unidade escolar.

h) Propostas de atividades da $6^{\mathrm{a}}$ série (ensino fundamental): entre as várias atividades desenvolvidas em sala de aula sobre o tema “Líderes Religiosos", sugeridas pelo volume 7 da Coleção de Livros Didáticos, "Descobrindo o Universo Religioso" (livro do aluno e livro do professor) e pelo Plano de Atividades recebido da Coordenação Geral de Ensino Religioso, vale mencionar: - identificação da biografia dos líderes que atualmente são conhecidos no mundo por meio de ações no campo da política, da ecologia, da ciência, do esporte e das tradições religiosas; 
- contação de histórias ou representação teatral sobre a vida, as virtudes e o legado dos líderes religiosos que marcaram a história da humanidade;

- produção de uma pequena estátua dos principais líderes religiosos estudados em sala de aula;

- realização de um concurso de frases sobre as virtudes mais admiráveis dos líderes religiosos.

i) Propostas de atividades da $7^{\mathrm{a}}$ série (ensino fundamental): entre as várias atividades desenvolvidas em sala de aula sobre o tema "Coexistência", sugeridas pelo volume 8 da Coleção de Livros Didáticos, "Descobrindo o Universo Religioso" (livro do aluno e livro do professor) e pelo Plano de Atividades recebido da Coordenação Geral de Ensino Religioso, vale mencionar:

- estudos no laboratório de informática da unidade escolar sobre a Mostra "Coexistence" que percorre o mundo, buscando sensibilizar as pessoas para a importância do respeito ao outro, do diálogo e da mútua convivência dos diversos;

- confecção de cata-ventos, levando em consideração o tema da "Coexistência";

- realização de um concurso de outdoors sobre o tema da "Coexistência";

- composição de uma coletânea de imagens que representem a importância da abertura à coexistência na sociedade brasileira e mundial;

- elaboração e apresentação uma breve peça de teatro sobre o tema da "Coexistência";

- apresentação de um curta (2 minutos) sobre o tema da "Coexistência";

- composição de letras musicais ou paródias a respeito do tema da "Coexistência", usando, para isso, palavras-chave da proposta de Ensino Religioso, tais como: fé, respeito, cultura, cidadania, diálogo, meio ambiente, diversidade religiosa, sociedade, etc.

j) Propostas de atividades da $8^{a}$ série (ensino fundamental): entre as várias atividades desenvolvidas em sala de aula sobre o tema "O papel do jovem nas comunidades religiosas”, sugeridas pelo volume 9 da Coleção 
de Livros Didáticos, "Descobrindo o Universo Religioso" (livro do aluno e livro do professor) e pelo Plano de Atividades recebido da Coordenação Geral de Ensino Religioso, vale mencionar:

- entrevista dentro da própria unidade escolar com vários jovens sobre quais são os sonhos deles em relação ao futuro, como eles se encontram posicionados em relação à vivência religiosa em suas vidas, o que pensam da tradição religiosa em que foram iniciados, se estão fazendo trabalhos na comunidade religiosa, etc; - inventário da participação e do protagonismo dos jovens nas comunidades religiosas circunvizinhas à unidade escolar e exposição em forma de painel em lugar de destaque da unidade escolar;

- realização de mesa redonda com representantes de diferentes tradições religiosas circunvizinhas à unidade escolar para discussão e relatos de como se dá o protagonismo dos jovens em cada uma delas.

Pelo detalhamento dessas atividades pode-se constatar que a proclamação do Ano Brasileiro do Ensino Religioso tem possibilitado fazer memória da história, do legado pedagógico e cívico da referida disciplina no atual contexto escolar. Tem possibilitado perceber as mais variadas possibilidades de levar o ser humano a posicionar-se para além do dinamismo da funcionalidade, característica mais evidente da sociedade atual. Tem possibilitado, enfim, o aluno que frequenta as salas de aula a entender a importância de se ater à evocação: "toma emprestado uma alma e um par de olhos, caso não os tenhas. A cada dia e a cada noite te alcança uma flecha alada, arremessada por um arco invisível. O que podes fazer, se não tens escudo? Curva tua vida" (RUMI, 1996, p. 71).

\section{Considerações finais}

$\mathrm{O}$ ato educativo transcende a ele mesmo. Transcende o conjunto de etapas de aprendizagem de um tema de estudo. Transcende os próprios objetivos propostos a determinada aprendizagem de um tema de estudo. O ato educativo abrange, de uma forma ou de outra, o todo da pessoa humana e leva o docente a esculpir de si e do discente a mais valiosa de todas as expressões artísticas: uma personalidade serena, equilibrada e permeada de plenitude. 
O Projeto "As Cores da Vida", elaborado e implementado nas unidades da Associação Franciscana de Ensino Senhor Bom Jesus, teve como objetivo, desde os seus primeiros esboços, mobilizar a comunidade escolar na celebração do Ano Brasileiro do Ensino Religioso, proclamado em 15 de outubro de 2009. Para além de uma celebração pontual de um ano comemorativo, as atividades do referido Projeto decorrem de uma proposta pedagógica e curricular implementada nas unidades da AFESBJ. Abrangem temáticas provenientes de uma proposta pedagógica e curricular de Ensino Religioso, tais como: a vida e as atitudes são como presentes; maneiras de falar com o Transcendente; a "regra de ouro" das religiões; os diversos nomes do Transcendente; os templos religiosos; a tradição oral e escrita; a origem das religiões, os símbolos religiosos, as principais festas; os líderes religiosos; a coexistência e o papel do jovem nas comunidades religiosas. Essas temáticas contribuem para não deixar, nem o docente e nem o discente, toscos ou desprovidos de encantamento pelo sentido da vida que se manifesta por meio da abertura ao Transcendente.

O Ensino Religioso pode, nesse sentido, contribuir de forma efetiva para a formação do aluno, oportunizando a ele o apreço pela sua dimensão religiosa e, principalmente, educá-lo como cidadão brasileiro a considerar e a respeitar as diferenças, sejam elas quais forem. Pois o Ensino Religioso não é mais, pela Lei 9.475 (BRASIL, 1997), um espaço na grade curricular das escolas para possíveis trabalhos catequéticos ou doutrinários de uma determinada confissão religiosa. O Ensino Religioso é, sim, uma disciplina escolar incumbida de oportunizar o conhecimento das manifestações do fenômeno religioso.

\section{Referências}

ALVES, L. A. S.; ALVES, M. H. L. Aspectos da diversidade religiosa. In: JUNQUEIRA, S. R. A. (Org.). O sagrado: fundamentos e conteúdos do Ensino Religoso. Curitiba: IBPEX, 2009. p. 143-155.

BOFF, L. Fundamentalismo: a globalização e o futuro da humanidade. Rio de Janeiro: Sextante, 2002.

BONHOEFFER, D. Ética. Tradução de Helberto Michel. 2. ed. São Leopoldo: Sinodal, 1991. 
BRASIL. Presidência da república. Lei n. 9.394, de 20 de dezembro de 1996. Estabelece as diretrizes e bases da educação nacional. Diário Oficial [da] República Federativa do Brasil, Poder Legislativo, Brasília, DF, 23 dez. 1996. p. 27833. Disponível em: <http://www6.senado.gov.br/legislacao/ ListaTextoIntegral.action?id=75723>. Acesso em: 23 jul. 2009.

. Presidência da República. Lei n. 9.475/97, de 22 jul. 1997. Alteração, normas, correlação, facultatividade, disciplina escolar, religião, estabelecimento de ensino, ensino fundamental, território nacional. competencia, sistema de ensino, fixação, conteúdo, disciplina escolar, religião. Diário Oficial [da] República Federativa do Brasil, Brasília, Congresso Nacional, 23 jul. 1997, coluna 2, p. 15824. Disponível em: < http://www6.senado.gov.br/legislacao/ListaNormas. action?tipo_norma $=$ LEI\&numero $=009475 \&$ data $=1997 \&$ SUBMIT1 $=$ Pesquis ar>. Acesso em: 21 jan. 2010.

FIGUEIREDO, A. P. O ensino religioso no Brasil: tendências, conquistas, perspectivas. Petrópolis: Vozes, 1996. p. 17-66.

GIL FILHO, S. F. Paisagem religiosa. In:JUNQUEIRA, S. R. A. (Org.). O sagrado: fundamentos e conteúdos do Ensino Religoso. Curitiba: IBPEX, 2009. p. 93-117.

GILZ, C. O livro didático de Ensino Religioso na formação do professor. Petrópolis: Vozes, 2009.

GRUEN, W. O Ensino Religioso na escola. 2. ed. Petrópolis: Vozes, 1995.

HARADA, H. Coisas, velhas e novas: à margem da espiritualidade franciscana. Bragança Paulista: IFAN, 2006.

MARIANO, A. L. S. Anotações sobre religião e formação de professores. Revista Lusófona de Ciência das Religiões, ano VI, n. 12, p. 109-116, 2007.

RORTY, R. Contingência, ironia e solidariedade. Lisboa: Presença, 1992.

RUMI, J. ud-D. Poemas místicos. Tradução e introdução de José Jorge de Carvalho. São Paulo: Attar, 1996.

Recebido: 23/10/2009

Received: 10/23/2009

Aprovado: 10/03/2010

Approved: 03/10/2010 